ARTICLE

\title{
Two new species of Microcotyle (Monogenea: Microcotylidae) on intertidal fish from the south Pacific coast
}

\author{
Dos nuevas especies de Microcotyle (Monogenea: Microcotylidae) en peces \\ intermareales de la costa del Pacífico sur
}

\author{
Gabriela Muñoz $^{1^{*}}$ and Mario George-Nascimento ${ }^{2}$ \\ ${ }^{1}$ Centro de Observación Marino para Estudios de Riesgos del Ambiente Costero (COSTA-R), Facultad de Ciencias del Mar y de Recursos \\ Naturales, Universidad de Valparaíso, Avenida Borgoño 16344, Viña del Mar, Chile \\ ${ }^{2}$ Centro de Investigaciones en Biodiversidad y Ambientes Sustentables (CIBAS), Facultad de Ciencias, Universidad Católica de la \\ Santísima Concepción, Alonso de Ribera 2850, Concepción, Chile \\ *Corresponding author: gabriela.munoz@uv.cl; gabriela.munoz@cienciasdelmar.cl
}

\begin{abstract}
Resumen.- El género Microcotyle es uno de los más diversos y controvertidos dentro de la familia Microcotylidae. A la fecha se han descrito 131 especies; sin embargo, más de la mitad han sido transferidos a otros géneros y varios otros tienen descripciones deficientes, por lo tanto menos de la mitad de las especies descritas podrían considerarse válidas. En Chile, se han reconocido dos especies de Microcotyle y existen registros de especímenes no identificados en varios peces costeros, pero que aún no han sido debidamente identificados. En este estudio se describe taxonómicamente, en base a datos morfológicos y moleculares (genes ITS2 y 18S), dos especies de Microcotyle encontrados en peces intermareales de la zona central $\left(33^{\circ} \mathrm{S}\right)$ y centro-sur $\left(36^{\circ} \mathrm{S}\right)$ de Chile: Microcotyle sprostonae $\mathrm{n}$. sp. (principalmente de Scartichthys viridis en el norte y centro de Chile) y M. chilensis $\mathrm{n}$. sp. (principalmente en Calliclinus geniguttatus de la zona centro-sur de Chile). Ambas especies de monogeneos se diferenciaron entre sí y de otras especies, principalmente en el número de testículos y clamps. Las dos nuevas especies también difieren entre sí, y con otras especies de Microcotyle secuenciadas hasta el momento, desde un par a varios pares de bases en los genes ITS2 y $18 \mathrm{~S}$. Los peces intermareales son mayoritariamente endémicos de la costa del Pacífico sudamericano, y tienen una distribución geográfica limitada que no se superpone con los hospedadores tipo de otras especies de Microcotyle. Por lo tanto, las especies aquí descritas se distinguen de sus congéneres por su morfología, genética y biología.
\end{abstract}

Palabras clave: Taxonomía, Monogenea, Microcotyle, peces intermareales, Océano Pacífico Sur, Chile

\begin{abstract}
Microcotyle is one of the most diverse and controversial genera within the family Microcotylidae. To date, 131 species have been described in Microcotyle; however, more than half have been transferred to other genera, and several others have poor descriptions. Therefore, less than half of all Microcotyle species may be considered valid. In Chile, two species have been recognized, and unidentified Microcotyle have been found on several littoral fish, but there has been no effort to properly identify them. In this study, two new species of Microcotyle are taxonomically described from intertidal fish of the central $\left(33^{\circ} \mathrm{S}\right)$ and south-central $\left(36^{\circ} \mathrm{S}\right)$ regions of Chile. In this study, Microcotyle sprostonae n. sp. (collected mainly from Scartichthys viridis in central Chile) and M. chilensis n. sp. (collected mainly from Calliclinus geniguttatus in south-central Chile) were identified based on morphological and molecular analyses (ITS2 and 18S genes). Both species of Microcotyle principally differed from one another and from other valid species in the number of testes and clamps. The two new species also differed from one another by one base pair in the ITS2 and $18 \mathrm{~S}$ genes and differed from other species of Microcotyle by several base pairs of both genes. Intertidal fish are mostly endemic to the Pacific coast of South America, and they have a limited geographical distribution that does not overlap with the type hosts of other Microcotyle species. Therefore, the two new species described here are distinguished from other congeneric species by morphological, genetic, and biological characteristics.
\end{abstract}

Key words: Taxonomy, Monogenea, Microcotyle, intertidal fish, South Pacific Ocean, Chile

\section{INTRODUCTION}

Microcotylidae Taschenberg, 1879 is one of the most controversial families within Monogenoidea Bychowsky, 1937, in which several genera and subgenera have been erected (e.g., Unnithan 1971, Caballero \& Bravo-Hollis 1972). Of the 58 genera described within Microcotylidae (Bray 2001), Microcotyle van Beneden and Hesse, 1863 is the most diverse genus, comprising 131 species that have been described from 1863 (Van Beneden \& Hesse 1863) to
2019 (Bouguerche et al. 2019a, b). The genus Microcotyle is mainly characterized by a conspicuous genital atrium with well-developed radial muscles, armed with numerous small, conical spines, and by a female reproductive system composed of a long, convoluted ovary, with an unarmed, long, single vaginal duct (see Mamaev 1989 for the emended diagnosis of the genus). Possibly 64 species of all those described correspond to Microcotyle (Bray 2001); however, several still require exhaustive revisions. 
In recent years, morphological descriptions have been complemented with genetic analysis, with both techniques allowing researchers to clarify species statuses (Verma et al. 2018) and verify the proposal of new species. Indeed, in the last decade molecular markers have been used in the identification of Microcotyle species (e.g., Hayward et al. 2007, Ayadi et al. 2017, Bouguerche et al. 2019a, b), although there are few species sequenced till now.

In Chile, two species of Microcotyle have been recorded in several fish species from different families (Muñoz \& Olmos 2007). These include M. nemadactylus Dillon and Hargis, 1965, from the fish Cheilodactylus variegatus Cuvier and Valenciennes, 1833 (Cheilodactylidae). Microcotyle moyanoi (Villalba and Fernández, 1986) (syn. Paramicrocotyle moyanoi) had been recorded on the fish Pinguipes chilensis (Molina, 1782) (Pinguipididae), Bovichthus chilensis Regan, 1913 (Bovichthidae), and Scartichthys gigas (Steindachner, 1876) (Blenniidae). Furthermore, unidentified species of Microcotyle have been recorded on subtidal fish species, such as Helicolenus lengerichi Norman, 1937, Sebastes oculatus Valenciennes, 1833 (Balboa \& George-Nascimento 1998, Gonzalez \& Moreno 2005), and on intertidal fish, such as Scartichthys viridis (Valenciennes, 1836), Auchenionchus crinitus (Jenyns, 1842), and A. variolosus (Valenciennes, 1836) (Díaz \& George-Nascimento 2002, Muñoz et al. 2002, Flores \& George-Nascimento 2009, Muñoz \& Delorme 2011, Muñoz \& Randhawa 2011, Muñoz \& Castro 2012).
Microcotylids found on different intertidal fish species, from the north $\left(23^{\circ} \mathrm{S}\right)$ to the south-central $\left(36^{\circ} \mathrm{S}\right)$ regions of Chile, have been identified as Microcotyle sp. (MuñozMuga \& Muñoz 2010) or as M. moyanoi (Díaz \& GeorgeNascimento 2002, Muñoz et al. 2002, Flores \& GeorgeNascimento 2009), which indicates there are doubts as to the taxonomical identification of these parasites. Since the first time Microcotyle was recorded as parasitizing an intertidal fish (on the blenny $S$. viridis) (Díaz \& George-Nascimento 2002), no researchers have examined the taxonomy of these monogeneans. Therefore, the objective of this study is to describe two species of Microcotyle parasitizing intertidal fish based on morphological and molecular analyses.

\section{MATERIALS AND METHODS}

\section{COLLECTION OF FISH AND MONOGENEANS}

Between 2014 and 2015, eight common fish species were collected from several rocky pools in different localities in Chile. There were 2,473 specimens obtained from central region (Valparaiso, between $33^{\circ} 26^{\prime} \mathrm{S}-71^{\circ} 41^{\prime} \mathrm{W}$ and $33^{\circ} 30^{\prime} \mathrm{S}-71^{\circ} 37^{\prime} \mathrm{W}$ ) and 1,076 from the central-south region (Biobío, between $36^{\circ} 28^{\prime} \mathrm{S}-72^{\circ} 55^{\prime} \mathrm{W}$ and $36^{\circ} 41^{\prime} \mathrm{S}-73^{\circ} 08^{\prime} \mathrm{W}$ ) of Chile (Table 1). Of these, it focused on the blenny Scartichthys viridis and the labrisomid Calliclinus geniguttatus, because they have the highest abundance and prevalence of microcotylid monogeneans.

Table 1. Species, sample sizes, and body lengths (BL) of fish collected from two zones of Chile. Prevalence (PRE, \%), abundance (ABU), and intensity range (INT) of microcotylids is shown. / Especies, tamaños muestreales y longitudes corporales (BL) de los peces recolectados desde dos zonas de Chile. Se muestra la prevalencia (PRE, \%), abundancia (ABU), y rango de intensidad (INT) de microcotílidos

\begin{tabular}{|c|c|c|c|c|c|c|c|c|c|c|}
\hline & \multicolumn{5}{|c|}{$\begin{array}{l}\text { M. sprostonae } \mathrm{n} . \mathrm{sp} \text {. } \\
\text { Central }\left(33^{\circ} \mathrm{S}\right)\end{array}$} & \multicolumn{5}{|c|}{$\begin{array}{l}\text { M. chilensis n. sp. } \\
\text { Central-South }\left(36^{\circ}\right)\end{array}$} \\
\hline & $\mathrm{N}$ & $\mathrm{BL}(\mathrm{cm})$ & PRE & $\mathrm{ABU}$ & INT & $\mathrm{N}$ & $\mathrm{BL}(\mathrm{cm})$ & PRE & $\mathrm{ABU}$ & INT \\
\hline \multicolumn{11}{|l|}{ BLENNIIDAE } \\
\hline H. sordidus* & 189 & $4.4 \pm 1.4$ & 0.5 & 0.01 & 1 & 156 & $7.0 \pm 1.5$ & 0.6 & 0.01 & 1 \\
\hline S. viridis* & 1643 & $7.7 \pm 3.5$ & 19.2 & 0.68 & $1-30$ & 220 & $10.5 \pm 5.0$ & 0 & 0 & \\
\hline \multicolumn{11}{|c|}{ BOVICHTHYDAE } \\
\hline B. chilensis* & 128 & $6.9 \pm 2.4$ & 0 & 0 & & 188 & $7.2 \pm 2.5$ & 1.6 & 0.31 & $1-55$ \\
\hline \multicolumn{11}{|l|}{ CLINIDAE } \\
\hline M. cristatus & 6 & $4.6 \pm 2.7$ & 0 & 0 & & 122 & $9.2 \pm 9.8$ & 0.8 & 0.01 & 1 \\
\hline \multicolumn{11}{|l|}{ LABRISOMIDAE } \\
\hline A. crinitus & 106 & $7.1 \pm 3.7$ & 1.9 & 0.02 & 1 & & & & & \\
\hline A. microcirrhis & 233 & $8.1 \pm 3.9$ & 0.4 & $<0.01$ & 1 & 3 & $13.3 \pm 5.0$ & 0 & 0 & \\
\hline A. variolosus* & 59 & $10.9 \pm 4.4$ & 3.4 & 0.07 & $1-3$ & 6 & $13.6 \pm 5.1$ & 16.7 & 0.17 & 1 \\
\hline C. geniguttatus* & 109 & $6.9 \pm 2.2$ & 1.8 & 0.02 & 1 & 381 & $7.6 \pm 2.3$ & 16.5 & 0.64 & $1-3$ \\
\hline
\end{tabular}

*Microcotyle specimens of fish used for molecular analyses 
Fish were collected with hand nets during low tide. Of the fish obtained, some were dissected immediately to collect monogeneans for morphological analysis. Each fish was euthanized with an overdose of an anesthetic solution before dissection, according to the bioethics protocols of the Universidad de Valparaíso and Universidad Católica de la SSMA Concepción. The gills were removed from the fish and observed under a light microscope. The monogeneans were collected and fixed in 5\% formalin for staining procedure or $96 \%$ ethanol for molecular analysis.

Monogeneans were stained with hematoxylin, dehydrated in a graded ethanol series (from $70 \%$ to $100 \%$ ), cleared in methyl salicylate, and mounted in Entellan. The specimens stained and mounted which were sufficiently clear to observe internal morphology were selected for the taxonomical description. The monogeneans were measured with an eyepiece micrometer. For the descriptions, the mean \pm the standard deviation, followed by the range of measurements in parentheses, were recorded and expressed in micrometers $(\mu \mathrm{m})$. Drawings were made with a camera lucida attached to a light microscope (Leica ${ }^{\circledR}$ DM LS2). The prevalence and mean intensity of the parasites was calculated according to Bush et al. (1997).

\section{Molecular ANALYSES}

Total genomic DNA from single specimens of Microcotyle from five fish species of the intertidal zone of central and central-south of Chile (Table 2), was extracted using established salt extraction procedures (Aljanabi \& Martinez 1997). A few microcotylid specimens of $S$. viridis from northern Chile $\left(23^{\circ} \mathrm{S}\right)$ were also considered for molecular analyses. Amplification of the ITS2 nuclear ribosomal DNA region was performed with the $3 \mathrm{~S}$ forward primer (5'-GGT ACC GGT GGA TCA CGT GGC TAG TG-3') (Bowles et al. 1993) and the ITS2.2 reverse primer (5'-CCT GGT TAG TTT CTT TTC CTCCG C-3') (Anderson \& Barker 1993). The $18 \mathrm{~S}$ rDNA fragments were amplified with the 18 SF forward primer (5'-AAG GTG TGM CCT ATC AAC

Table 2. Species of the Microcotylidae used in molecular analyses in the present study / Especies de Microcotylidae usadas en los análisis moleculares en el presente estudio

\begin{tabular}{|c|c|c|c|c|c|}
\hline Parasite species & Fish species & Locality & $\begin{array}{c}18 \mathrm{~S} \\
\text { GenBank \# }\end{array}$ & $\begin{array}{c}\text { ITS2 } \\
\text { GenBank \# }\end{array}$ & Source \\
\hline \multirow[t]{3}{*}{ M. sprostonae $\mathrm{n} . \mathrm{sp}$. } & Scartichthys viridis & Valparaíso, Chile & MN429297 & $\begin{array}{l}\text { MN429299, } \\
\text { MN429308, } \\
\text { MN429309, } \\
\text { MN429310 }\end{array}$ & This study \\
\hline & & Antofagasta, Chile & & $\begin{array}{l}\text { MN429304, } \\
\text { MN429305, } \\
\text { MN429306 }\end{array}$ & \\
\hline & Hypsoblennius sordidus & Valparaíso, Chile & & MN429302 & This study \\
\hline \multirow[t]{4}{*}{ M. chilensis $\mathrm{n}$. sp. } & Calliclinus geniguttatus & Bio-Bio, Chile & $\begin{array}{l}\text { MN429295, } \\
\text { MN429296 }\end{array}$ & $\begin{array}{l}\text { MN429303, } \\
\text { MN429312, } \\
\text { MN429313 }\end{array}$ & This study \\
\hline & Auchenionchus variolosus & Biobío, Chile & MN429294 & MN429311 & This study \\
\hline & Bovichthys chilensis & Biobío, Chile & MN429293 & $\begin{array}{l}\text { MN429301, } \\
\text { MN429314 }\end{array}$ & This study \\
\hline & Hypsoblennius sordidus & Biobío, Chile & MN429292 & MN429300 & This study \\
\hline Microcotyle sp. & Sebastes oculatus & Valparaiso, Chile & MN429298 & MN429307 & This study \\
\hline M. sebastis & Sebastes sp. & & AJ287540 & & Littlewood \& Olson (2001) \\
\hline M. erythrinii & Pagellus erythrinus & France & AM157195 & & Badets et al. (2011) \\
\hline Microcotylidae gen sp. & Argyrops spinifer & Oman Sea & JN602094 & & Yoon et al. 2013 \\
\hline Polylabris sp. & Siganus fuscescens & China & HM545905 & & Wang et al. (unpublished)* \\
\hline Cynoscionicola branquialis & & & AJ287495 & & Littlewood \& Olson (2001) \\
\hline Bivagina pagrosomi & Chrysophrys auratus & & AJ228775 & & Littlewood \& Olson (2001) \\
\hline Neomicrocotyle pacifica & Caranx hippos & & AJ228787 & & Littlewood \& Olson (2001) \\
\hline Microcotyle bassensis & Platycephalus sp. & Port Lincoln, Australia & & EF452636 & Hayward et al. (2007) \\
\hline Microcotyle pomatomi & Pomatomus sp. ** & Moreton Bay, Australia & & EF452637 & Hayward et al. (2007) \\
\hline Anchoromicrocotyle gaymensis & Atractoscion nobilis & California, USA & & EF452635 & Hayward et al. (2007) \\
\hline Diplostamenides sciaenae & Pennahia argentata & Kagawa Pref, Japan & & EF452639 & Hayward et al. (2007) \\
\hline Sciaenacotyle sciaenicola & Argyrosomus japonicus & Port Lincoln, Australia & & EF452634 & Hayward et al. (2007) \\
\hline \multirow[t]{2}{*}{ Zeuxapta seriolae (Outgroup) } & Seriola hippos & Harbor, Australia & AJ228797 & & Littlewood \& Olson (2001) \\
\hline & Seriola lalandi & Adelaide, Australia & & EF452638 & Hayward et al. (2007) \\
\hline
\end{tabular}

* References got from GenBank, Wang JY, Lu YS, Wu ZH \& Jian JC. Studies on biodiversity and population ecology of the parasites from Siganus fuscescens in Zhanjiang sea area (Unpublished data).

**The fish species was indicated as Pomatomus pomatomi, probably a mistake, because this is not recorded in public data base (www.fishbase.org and www.marinespecies.org) 
T-3') and the 18SR reversed primer (5'-TTA CTT CCT CTA AAC GCT C-3'). The ITS2 and $18 \mathrm{~S}$ regions in the sequences were determined using the Internal Transcribed Spacer 2 Ribosomal RNA Database website (from NCBI GenBank) ${ }^{1}$.

PCR (Polymerase Chain Reaction) amplification for $18 \mathrm{~S}$ rDNA was performed using 100- $\mu 1$ mixtures containing 200 ng of genomic DNA, $0.2 \mu \mathrm{M}$ of each of the two primers, $50 \mu \mathrm{M}$ of each of the dNTPs, $1 \times$ PCR buffer (with $2 \mathrm{mM}$ $\mathrm{MgCl} 2$ ), and $2.5 \mathrm{U}$ of ExTaq DNA polymerase (Takara). Thermocycling conditions were as follows: $94{ }^{\circ} \mathrm{C}$ for 5 min, followed by 30 cycles of $94{ }^{\circ} \mathrm{C}$ for $30 \mathrm{~s}, 54^{\circ} \mathrm{C}$ for 30 $\mathrm{s}$, and $72^{\circ} \mathrm{C}$ for $1 \mathrm{~min}$. A final extension was performed at $72{ }^{\circ} \mathrm{C}$ for $5 \mathrm{~min}$.

PCR reactions for ITS2 rDNA were performed using the same reaction mixture as described above and the following thermocycling program: initial denaturation at $95^{\circ} \mathrm{C}$ for 10 min, followed by a touchdown of 10 cycles of $95^{\circ} \mathrm{C}$ for 15 $\mathrm{s}, 60-50{ }^{\circ} \mathrm{C}$ for $30 \mathrm{~s}$, and $72{ }^{\circ} \mathrm{C}$ for $45 \mathrm{~s}$. This was followed by the second stage of 35 cycles of $95^{\circ} \mathrm{C}$ for $15 \mathrm{~s}, 50^{\circ} \mathrm{C}$ for $30 \mathrm{~s}$, and $72{ }^{\circ} \mathrm{C}$ for $45 \mathrm{~s}$. A final extension of $72{ }^{\circ} \mathrm{C}$ for 30 min was performed (Peña et al. 2014). PCR products were visualized on $0.8 \%$ agarose gels using a $1 \times$ sodium borate (SB) buffer solution.

The final PCR products for the $18 \mathrm{~S}$ and ITS2 rDNAgenes were purified and sequenced using the service of Macrogen, South Korea. Sequencher ${ }^{\mathrm{TM}}$ version 4.5 (GeneCodes Corporation) was used to analyze the sequences. Analyses were conducted using the Kimura 2-parameter model (Kimura 1980). All positions with less than 95\% site coverage were eliminated. More than 5\% alignment gaps, missing data, or ambiguous bases were not allowed at any position. For the $18 \mathrm{~S}$ rDNA gene, the analysis involved 22 nucleotide sequences and a total of 1,493 positions in the final dataset. For the ITS2 gene, the analysis involved 22 nucleotide sequences and a total of 371 positions in the final dataset.

Genetic sequences of Microcotyle species of this study were contrasted to other microcotylid species; M. sebastis and $M$. erythrinii were used for the $18 \mathrm{~S}$ gene, and $M$. bassensis and $M$. pomatomi were used for the ITS2 gene, including other species of Microcotylidae listed in Table 2. Evolutionary analyses were conducted using MEGA6 (Tamura et al. 2013). The genetic distances were computed with the total number of mutations, and the divergences were calculated among individuals by applying three algorithms: NJ (neighbor-joining), ML (maximum likelihood), and MP (maximum parsimony) (Tateno et al. 1994).

\section{Results}

\section{SPECIES DESCRIPTIONS}

Family Microcotylidae Taschenberg, 1879

Genus Microcotyle van Beneden and Hesse, 1863

Microcotyle sprostonae n. sp. (Fig. 1 A-I)

Description (based on 20 mature and stained specimens): Body elongated, fusiform and flattened dorsoventrally, $3917 \pm 522$ (3062-5225) long and $883 \pm 156$ (687-1250) wide at the ovary level. Thin and smooth tegument. A pair of anterior, oval suckers, $75 \pm 9$ (52-87) long and $65 \pm 7$ (55-85) wide, with a thin septum located at the middle of each sucker. One row of minute papillae on the anterior portion of each sucker. Oral suckers from $43 \pm 13$ (25-69) from the anterior edge. Mouth subterminal, immediately anterior to the pharynx. Pharynx oval to spherical $58 \pm 10$ (44-75) long and $51 \pm 6$ (37-62) wide. Brain almost circular, at the middle of esophagus level. Two lateral nervous cords. Esophagus $292 \pm 64$ (137-387) long and $19 \pm 6$ (12-25) wide, with a pair of short lateral diverticula. Gut bifurcates post atrium, at $434 \pm 61$ (350-600) from the anterior edge. Caeca laterally ramified, one caecum larger than the other. Last part of caeca without ramification, extend up to the mid-level of the haptor. The gut epithelium, from esophagus up to the end of caeca with pigmented cells.

Genital atrium cavity from oval to as a triangle shape with rounded corners, $101 \pm 43$ (60-250) long and $135 \pm$ 23 (106-181) wide, with anterior wide and rounded border, covered by little spines. Spines also on the peripheral atrium cavity and inside the cavity, which are difficult to count, approximately 200 spines of similar size, $11 \pm 2(8-15)$ long. Posterior to the atrial cavity, a concave zone in which the cirrus evert, surround by muscular fibers. Two groups of spines located posterior-laterally to cirrus cavity, with $7 \pm 1$ (4-9) spines each group. Atrial cavity surrounded by radial muscles, making a conspicuous atrial zone, $179 \pm 47$ (125-262) long, including the cirrus cavity, and $185 \pm 74$ (215-475) wide, considering the radial muscles.

Ovary pre-testicular, intercaecal, glomerular and long. The portion with immature cells coiled. The portion of the ovary with mature cells as an inverted $\mathrm{U}$, located at 1,519 \pm 198 (1,200-2,050) from the anterior end of the body. Ovary maximum wide $109 \pm 30$ (75-175). Oviduct a long folded tube, connected to an oval seminal receptacle and posteriorly to the vitelline duct. Oviduct turns upwards, followed by the ootype. Ootype almost oval shape, 330 \pm 28 (310-350) long. Mehlis' cells different sizes, short at the beginning and at the end of the ootype (11-18 $\mu \mathrm{m})$, and large cells at the middle of the ootype $(24-30 \mu \mathrm{m})$. Uterus

${ }^{1}<$ https://www.ncbi.nlm.nih.gov/genbank> 


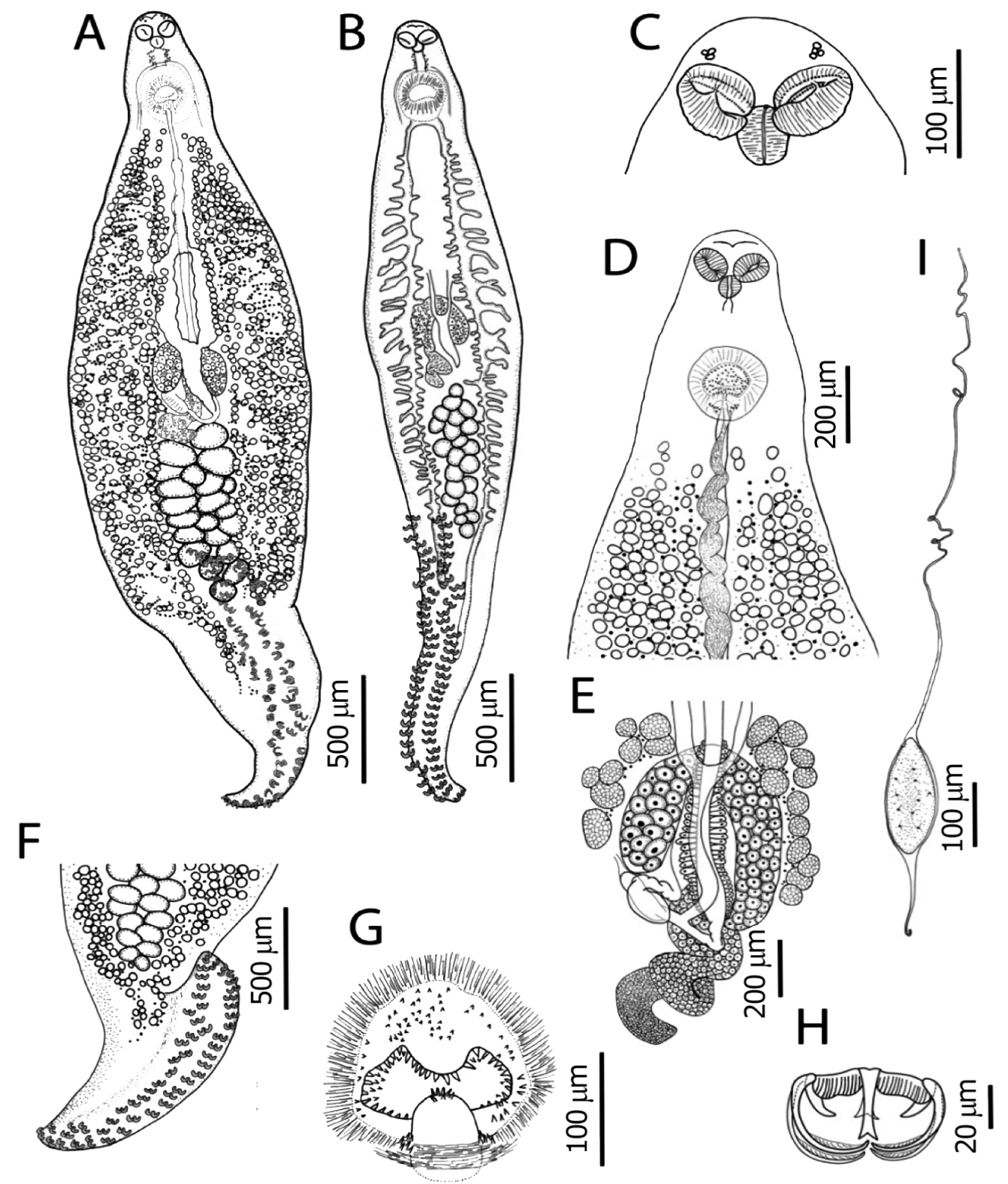

Figure 1. Drawings of Microcotyle sprostonae $\mathrm{n}$. sp. A) Ventral view of whole body, B) Ventral view of whole body showing the digestive tract (vitelline glands not drawn), C) oral suckers and pharynx, D) anterior portion of the body, E) female reproductive organs, F) haptor, G) genital atrium, H) clamp, I) egg / Dibujos de Microcotyle sprostonae n. sp. A) Vista ventral del cuerpo completo, B) Vista ventral de cuerpo complete que muestra el tracto digestivo (glándulas vitelinas no dibujadas), C) ventosas orales y faringe; D) parte anterior del cuerpo, E) órganos reproductores femeninos, F) haptor, G) atrio genital, H) clamp, I) huevo

tubular, intercaecal, extending up to the atrial cavity. Vitelline glands glomerulated, located laterally in both sides of the body, extending from gut bifurcation up to the haptor mid-level. Two vitelline ducts, intercaecal, at the middle of the body. Vitelline ducts replete with reserves in some specimens. Vitelline ducts united posteriorly and anteriorly; posterior union in short conduct which joined to oviduct; anterior union connect with the vitello-vaginal duct. Female genital pore dorsal, at $717 \pm 45$ (675-787) from the anterior edge. A short muscular vagina that gradually connects with a short vitelline duct. Female genital pore located at $490 \pm 91(425-595)$ from the vitelline duct bifurcation, and $308 \pm 96(240-475)$ from the posterior border of the atrium cavity.
Nine specimens with eggs. One mature egg per monogenean. In two specimens, another egg in development. Egg fusiform, $213 \pm 22$ (175-237) long and $76 \pm 13$ (56-95) wide, with polar filaments, one short $79 \pm 29(75-80)$ directed to posterior side and the other much longer than 10 times the egg length, directed to the genital opening.

Testes intercaecal, post-ovary, from oval to irregular shape, $101 \pm 28$ (50-150) long and $114 \pm 34$ (70-200) wide. Number of testes $25 \pm 3$ (21-31). Seminal vesicle long, located between the ovary and ootype; continuing ventrally along with the uterus. Cirrus oval, $72 \pm 25$ (54-90) long, $47 \pm 7$ (41-55), with 7-8 spines on the top, observed in two specimens.

Vol. 54, N³, 2019 Revista de Biología Marina y Oceanografía 
Haptor symmetrical, $1232 \pm 204$ (975-1750) long, 207 \pm 38 (150-312) wide, with two lateral rows, each sidewith 29-40 clamps, microcotyle-type, with a total of $68 \pm 8$ (5883 ) clamps. Clamps oval, the most anterior slightly smaller than others. Clamps size, at the middle of haptor, $76 \pm 11$ (69-119) long and $45 \pm 8$ (34-56) wide.

\section{TAXONOMY SUMMARY}

Syns: Paramicrocotyle moyanoi sensu Díaz \& GeorgeNascimento (2002), Flores \& George-Nascimento (2009); Microcotyle sp. sensu Muñoz-Muga \& Muñoz (2010), Díaz \& Muñoz (2010), Muñoz \& Delorme (2011), Muñoz \& Randhawa (2011), Muñoz \& Castro (2012).

Type host: Scartichthys viridis (Valenciennes, 1836) (Pisces: Blenniidae).

Other hosts: Hypsoblennius sordidus (Bennet, 1928) (Pisces: Blenniidae)

Site of infection: Gills.

Type locality: Las Cruces ( $\left.33^{\circ} 29^{\prime} \mathrm{S}, 71^{\circ} 38^{\prime} \mathrm{W}\right)$, Chile.

Other locality: Antofagasta $\left(23^{\circ} 27^{\prime} \mathrm{S}, 70^{\circ} 36^{\prime} \mathrm{W}\right)$; Isla Negra $\left(33^{\circ} 25^{\prime} \mathrm{S}, 71^{\circ} 41^{\prime} \mathrm{W}\right)$, El Tabo (33⒉ $\left.7^{\prime} \mathrm{S}, 71^{\circ} 40^{\prime} \mathrm{W}\right)$, Maitencillo $\left(33^{\circ} 16^{\prime} \mathrm{S}, 71^{\circ} 40^{\prime} \mathrm{W}\right)$, Tunquén $\left(33^{\circ} 37^{\prime} \mathrm{S}\right.$, $\left.71^{\circ} 27^{\prime} \mathrm{W}\right)$ and Quintero $\left(33^{\circ} 45^{\prime} \mathrm{S}, 71^{\circ} 30^{\prime} \mathrm{W}\right)$, Chile.

Prevalence and intensity: $13.3 \%$ prevalence and an intensity range of 1-3 on $30 \mathrm{~S}$. viridis at the type locality; $100 \%$ prevalence and range intensity of 2-4 on three S. viridis at Antofagasta; infections in other hosts are indicated in Table 1.

Deposition of types of specimens: MNHNCL PLAT15016 (Holotype); MNHNCL PLAT-15017 (Paratype).

Etymology: "sprostonae" is dedicated to Nora Georgina Sproston, who made important contributions to the taxonomy of monogeneans.

\section{REMARKS}

M. sprostonae n. sp. was compared to all other species based upon two features: the number of testes and number of clamps. Species of the Microcotyle that have 20-30 testes and 60-90 clamps were chosen, similar to specimens of $M$. sprostonae $\mathrm{n}$. sp. Thus, the two species examined that resembled M. sprostonae n. sp. were M. ditrematis Yamaguti, 1940 and M. emmelichthyops Yamaguti, 1968.

M. sprostonae n. sp. differs from $M$. ditrematis in pharynx size (44-75 long $\times 37-62$ wide $v$ s. 30-32 long $\times$ 33-35 wide), oral suckers (52-87 long 55-85 wide $v s$. 3342 long $\times 39-42$ wide), and genital atrium width (106-181 vs. 90 maximum width, without surrounding muscles, see Yamaguti 1940).
M. sprostonae n. sp. differs from M. emmelichthyops with regard to clamps, displaying a significant difference in the maximum number (58-83 vs. 62-115). Additionally, the genital atrium of $M$. emmelichthyops has "an oval bulb of lamellar muscle fibers," and the clamp structure contains a styliform median piece enclosed in a capsulelike structure at the base, specifically in the median bifid sclerite (Yamaguti 1968), which is not present in $M$. sprostonae $\mathrm{n}$. $\mathrm{sp}$.

M. sprostonae $\mathrm{n}$. sp. differs from the other two Microcotyle species previously recorded in Chile, $M$. nemadactylus and M. moyanoi. M. sprostonae $\mathrm{n}$. sp. shows a smaller number of clamps (53-83 vs. 90-104) and shorter clamp length (34-56 vs. 63-77) than M. nemadactylus (Dillon \& Hargis 1965), whereas M. sprostonae n. sp. shows smaller numbers of clamps and testes than $M$. moyanoi (clamps: 52-83 vs. 118-150; testes: 21-31 vs. 33-44) (Villalba \& Fernández 1986).

The distribution of microcotylids and hosts also supports $M$. sprostonae n. sp. as a new species. This monogenean was recorded in northern and central Chile on six fish species, but with a notorious preference for $S$. viridis (Table 1). The fish hosts of M. sprostonae $\mathrm{n}$. sp. are mostly endemic to the Pacific coast of South America, whereas $M$. ditrematis has been recorded on Ditrema temminki at the Japanese coast (Yamaguti 1940), and $M$. emmelichthyops has been found on Emmelicthys sp. in Hawaii (Yamaguti 1968).

\section{Microcotyle chilensis n. sp. (Fig. 2 A-F)}

Description (based on 14 stained specimens): Body elongated, fusiform and flattened dorsoventrally, 3,169 \pm 674 (2,187-4,062) long, $705 \pm 182(475-1,125)$ wide at the level of the ovary. Thin and smooth tegument. A pair of oral, rounded suckers, $55 \pm 6$ (45-65) long, $52 \pm 8$ (35-63) wide, with a thin septum located at the middle of each sucker. One row of minute papillae on the anterior portion of the sucker. Oral suckers $46 \pm 14$ (25-62) from the anterior edge. Mouth subterminal, immediately anterior to the pharynx. Pharynx almost spherical, $63 \pm 8$ (50-75) long, $64 \pm 8$ (56-81) wide. The brain at the middle of the esophagus, nervous cords directed posteriorly and laterally. Esophagus $265 \pm 69$ (152-375) long; diverticula not observed. Gut bifurcates post atrium, at a distance of $450 \pm 106$ (300-625) from the anterior edge. Caeca laterally ramified, from esophagus up to the end of the body reaching some part of the haptor. The gut epithelium with pigmented cells.

Genital atrium shape was similar in structure to $M$. sprostonae $\mathrm{n}$. sp. Atrial cavity $83 \pm 18$ (50-120) long and $128 \pm 22$ (75-162) wide. Peripheral spines on the atrium cavity, $12 \pm 2$ (7-15) long, also spines inside the genital 

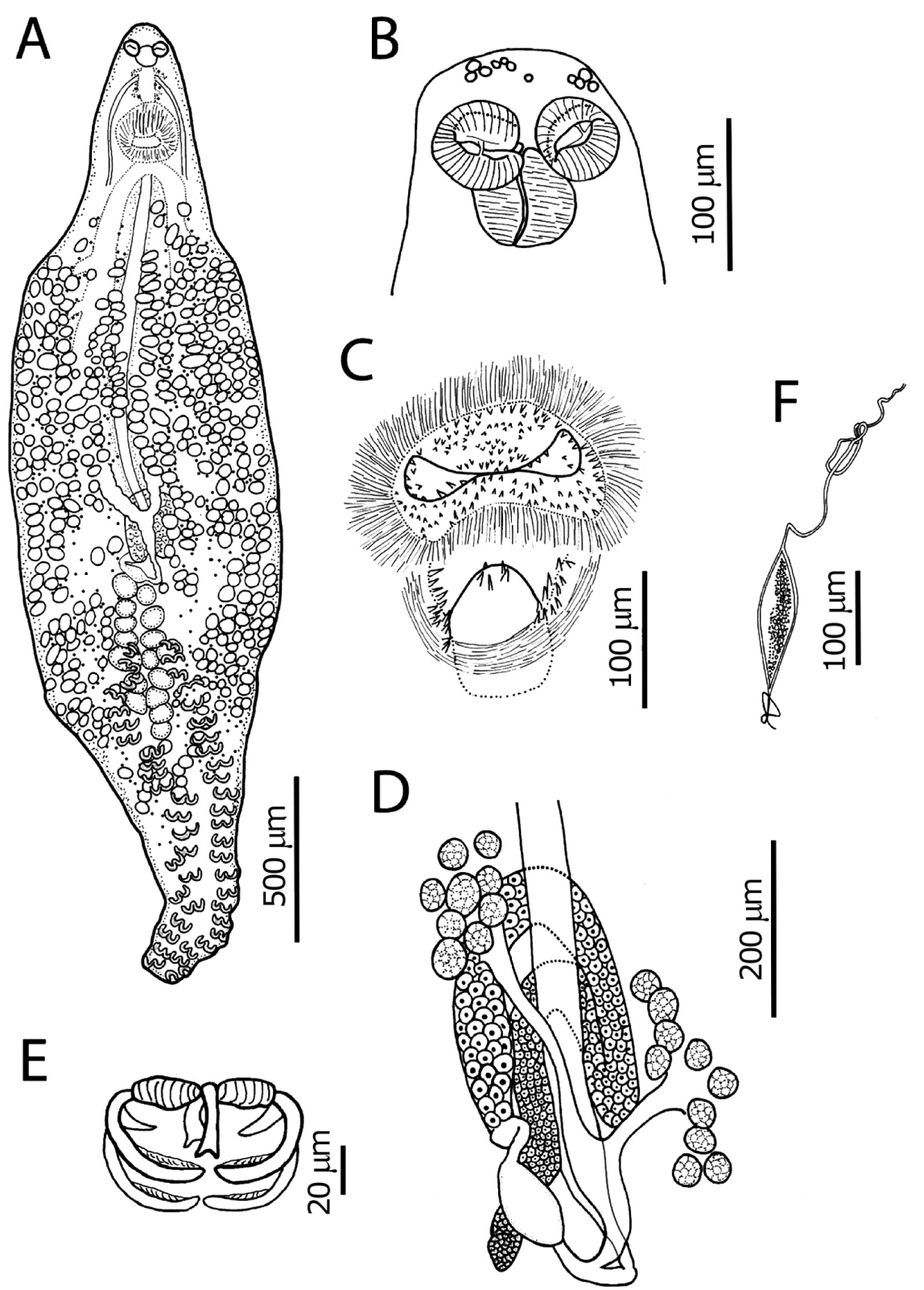

Figure 2. Drawings of Microcotyle chilensis $n$. sp. A) Ventral view of whole body, B) prohaptor, C) genital atrium, D) female reproductive organs, E) clamp, F) egg / Dibujos de Microcotyle chilensis n. sp. A) Vista ventral del cuerpo completo, B) prohaptor, C) atrio genital, D) órganos reproductores femeninos, E) clamp, F) huevo

cavity. More than 200 spines of similar size in the atrium cavity. Posteriorly, a cirrus cavity as a concave depression, surround by muscular fibers, armed with two groups of spines located posterior-laterally to this cavity, with $11 \pm$ 2 (7-14) spines each group. Atrial cavity surrounded by radial muscles, making a conspicuous atrial zone, $163 \pm$ 44 (100-225) long and $187 \pm 46$ (113-250) wide including the cirrus cavity.

Ovary pretesticular, intercaecal glomerular and long twisted extremes; the portion of the ovary with mature cells as an inverted $U$, located at $1650 \pm 440$ (1050-2310) from the anterior end of the body. Ovary maximum wide $94 \pm 35$ (62-175). Ootype oval, $131 \pm 33$ (100-165) long, $41 \pm 10$ (31-60) wide, located posterior to mature part of the ovary. Oviduct a long folded tube, connected to an oval seminal receptacle and posteriorly to the vitelline duct. Oviduct turns upwards, followed by oval, long ootype. Uterus tubular, intercaecal, extending up to atrial cavity. Vitelline glands glomerulated, located laterally in both sides of the body, extending from some distance to gut bifurcation, at $600 \pm 137$ (350-800) from the anterior end of the body. Vitelline ducts united posteriorly. The anterior union of vitelline ducts was not observed in most 
specimens. Anterior union of vitelline conducts connect with the vitello-vaginal duct. Female genital pore dorsal, located at $638 \pm 187$ (475-900) from the anterior edge. A short muscular vagina that gradually connects with a short vitelline duct. Female genital pore located at $357 \pm 201$ (215-500) from the vitelline duct bifurcation, and $283 \pm 80$ (225-375) from the posterior border of the atrium cavity.

Eight specimens with eggs. One or two eggs per monogenean. Egg fusiform, $224 \pm 30$ (175-256) long, $71 \pm 30$ (50-110) wide, with polar filaments, one short, approximately $100 \mu \mathrm{m}$, directed to the genital opening, the other longer than 10 times the egg length.

Testes intercaecal, post-ovary, from oval to irregular shape, $81 \pm 31$ (50-125) long and $65 \pm 7$ (55-72) wide. Number of testes $17 \pm 2$ (14-18). Seminal vesicle long, ventrally located along with the uterus. Cirrus oval, approximately 100 long, $64 \pm 5$ (62-70) wide, with two little spines on the top, observed in just one specimen.

Haptor symmetrical, $863 \pm 125$ (700-1090) long, 285 \pm 53 (200-350) wide, with two lateral rows with clamps, 20-28 on the right and 21-27 on the left. Clamp as usual for Microcotyle. A total of $48 \pm 3$ (44-54) clamps. Clamps similar in structure and size, $85 \pm 9$ (75-100) long and 51 \pm 6 (44-62) wide, at the middle of the haptor.

\section{TAXONOMY SUMMARY}

Sym: Paramicrocotyle moyanoi sensu Muñoz et al. (2002).

Type host: Calliclinus geniguttatus (Valenciennes, 1836) (Labrisomidae).

Other hosts: Auchenionchus variolosus (Valenciennes, 1836) (Labrisomidae), Bovichthus chilensis Regan, 1913 (Bovichtidae), and Hypsoblennius sordidus (Bennet, 1928) (Blenniidae).

Site of infection: Gills.

Type locality: Burca $\left(36^{\circ} 28^{\prime} \mathrm{S}, 72^{\circ} 55^{\prime} \mathrm{W}\right)$, Chile.

Other locality: Cantera $\left(36^{\circ} 41^{\prime} \mathrm{S}, 73^{\circ} 08^{\prime} \mathrm{W}\right)$ and Merquiche $\left(36^{\circ} 29^{\prime} \mathrm{S}, 72^{\circ} 54^{\prime} \mathrm{W}\right)$, Chile.

Prevalence and intensity: 5.9\% of prevalence and intensity range of 1-12 on 268 C. geniguttatus at the type locality; infections in other hosts are indicated in Table 1.

Deposition of types of specimens: MNHNCL PLAT15014 (Holotype); MNHNCL PLAT-15015 (Paratype).

Etymology: "chilensis" referred to the country where this monogenean was found.

\section{REMARKS}

Microcotyle chilensis n. sp. was compared to other species, which were selected according to two features: 10-20 testes and 40-60 clamps. Four species resembled M. chilensis n. sp.: M. hiatulae Goto, 1899, M. furcata Linton, 1940, M. pentapodi Sandars, 1944, and M. neozealanicus Dillon and Hargis, 1965.

Microcotyle hiatulae has been poorly described, based only on body length, number of clamps and testes, and spine lengths on the genital atrium (Goto 1899). Thoney \& Munroe (1987) redescribed M. hiatulae and considered it as a senior synonym of $M$. furcata. We used data from that redescription and found that, compared to the new species, M. chilensis n. sp. differs from M. hiatulae in a smaller oral sucker length (45-65 vs. 44-112) and in the ratio of haptor length to /body length (20-34\% vs. 23.4-48.1\%). M. chilensis n. sp. also has a genital atrium at a greater distance from the anterior edge compared to $M$. hiatulae (8-30\% vs. $7.3-12.4 \%$ ), and the ratio of the oral sucker length to pharynx length was greater in M. chilensis $\mathrm{n}$. sp. than in M. hiatulae (0.75-1.04 vs. 0.92-1.34) .

M. pentapodi was described using measurements of the holotype and the average of the morphometric measurements, which made it difficult to know the morphometric variability of the species. The average length and width of the body were smaller in M. pentapodi $(2,060 \times 250)$ than in M. chilensis n. sp. $(3,169 \times 705)$. Oral suckers were longer in M. pentapodi than in M. chilensis n. sp. (63 vs. 52), and the pharynx was smaller in M. pentapodi than in M. chilensis n. sp. (length and width: $50 \times 33$ vs. 64 $\times 64$ ). Moreover, M. pentapodi was described as having a particularly shaped genital atrium: a "sucker with a pair of saccular bags without spines" positioned to the right and to the left of the sucker (Sandars 1944). Sandars distinguished this species from others using this distinctive genital atrium shape. However, the general morphology of the genital atrium of M. pentapodi seems similar to most Microcotyle, although the way to represent this was confusing. Overall, the description of the morphology of this structure in $M$. pentapodi requires some revision.

It is worth noting that M. pentapodi has been transferred to the genus Manterella Unnithan, 1971, due to the shape of the genital atrium. However, Mamaev (1977) considered this genus to be a synonym of Cynoscionicola Yamaguti, 1963. However, the genital atrium of $M$. pentapodi was not well described and drawings conveyed a poor representation of this structure. Therefore, the status of this species is unclear. 
M. chilensis n. sp. differs from M. neozealanicus with regard to several traits. $M$. chilensis $\mathrm{n}$. $\mathrm{sp}$. has a larger body size (2187-4062 × 475-1125) than M. neozealanicus (1460$2920 \times 460-770)$. The pharynx is also bigger in M. chilensis n. sp. $(54-75 \times 56-81)$ compared to M. neozealanicus (44-62 $\times$ 47-61), and the distance between the vagina opening and genital atrium is larger in M. chilensis n. sp. (225-375) than in M. neozealanicus (115-191) (see Dillon \& Hargis 1965).

Of the other Microcotyle species previously recorded in Chile, M. nemadactylus (clamps: 90-104; testes: 1625) (Dillon \& Hargis 1965) and M. moyanoi (clamps: 118-150; testes: 33-44) (Villalba \& Fernández 1986) are morphologically distinct from $M$. chilensis n. sp. (clamps: 44-54; testes: 14-18). M. chilensis n. sp. shares several morphological and morphometrical traits with $M$. sprostonae n. sp., but they differ in the number of testes, and there is only a small overlap in the number of clamps (Table 4). The cirrus cavity length is 37-112 in M. chilensis n. sp., which is in contrast to 12-50 in M. sprostonae $\mathrm{n}$. $\mathrm{sp}$. There are also differences in the number of spines on the sides of the cirrus cavity (4-9 in M. sprostonae $\mathrm{n}$. sp. vs. 7-14 in M. chilensis n. sp.). Other differences are in relative measurements, such as larger ratio between oral sucker length and pharynx length and larger distance from posterior edge to last vitellarium gland in M. sprostonae n. sp. than M. chilensis n. sp. (Table 3).
The distribution of parasites and hosts might support M. chilensis as a new species. Similar to the hosts of $M$. sprostonae $\mathrm{n}$. sp., the fish hosts analyzed here are mostly endemic to the Pacific coast of South America, and they are farther away than the type localities of $M$. hiatulae, which are found in the fish Tautoga onitis from Newport, Rhode Island, in the United States (Thoney \& Munroe 1987). M. pentapodi has been found on Pentapodus milii fish in Western Australia (Sandars 1944), and M. neozealanicus has been found in Helicolenus percoides in New Zealand (Dillon \& Hargis 1965). M. chilensis n. sp. was recorded in south-central Chile on five intertidal fish species, but with a notorious preference for $C$. geniguttatus (Table 1 ), contrasting with the distribution of $M$. sprostonae n. sp. in northern and central Chile. However, with the information obtained in this study, it is not possible to confirm the existence of geographical overlapping between M. sprostonae n. sp. and M. chilensis n. sp.

\section{Molecular aNALYSES}

Based on the $18 \mathrm{~S}$ gene, there were two clades of Microcotyle in the samples used in this study. One included a specimen $M$. sprostonae n. sp. from S. viridis (Fig. 3) from central Chile $\left(33^{\circ} \mathrm{S}\right)$, and the other was obtained from different fish species (C. geniguttatus, Auchenionchus variolosus, $B$. chilensis, and $H$. sordidus) from the southcentral region of Chile ( $\left.36^{\circ} \mathrm{S}\right)$ (Fig. 3).

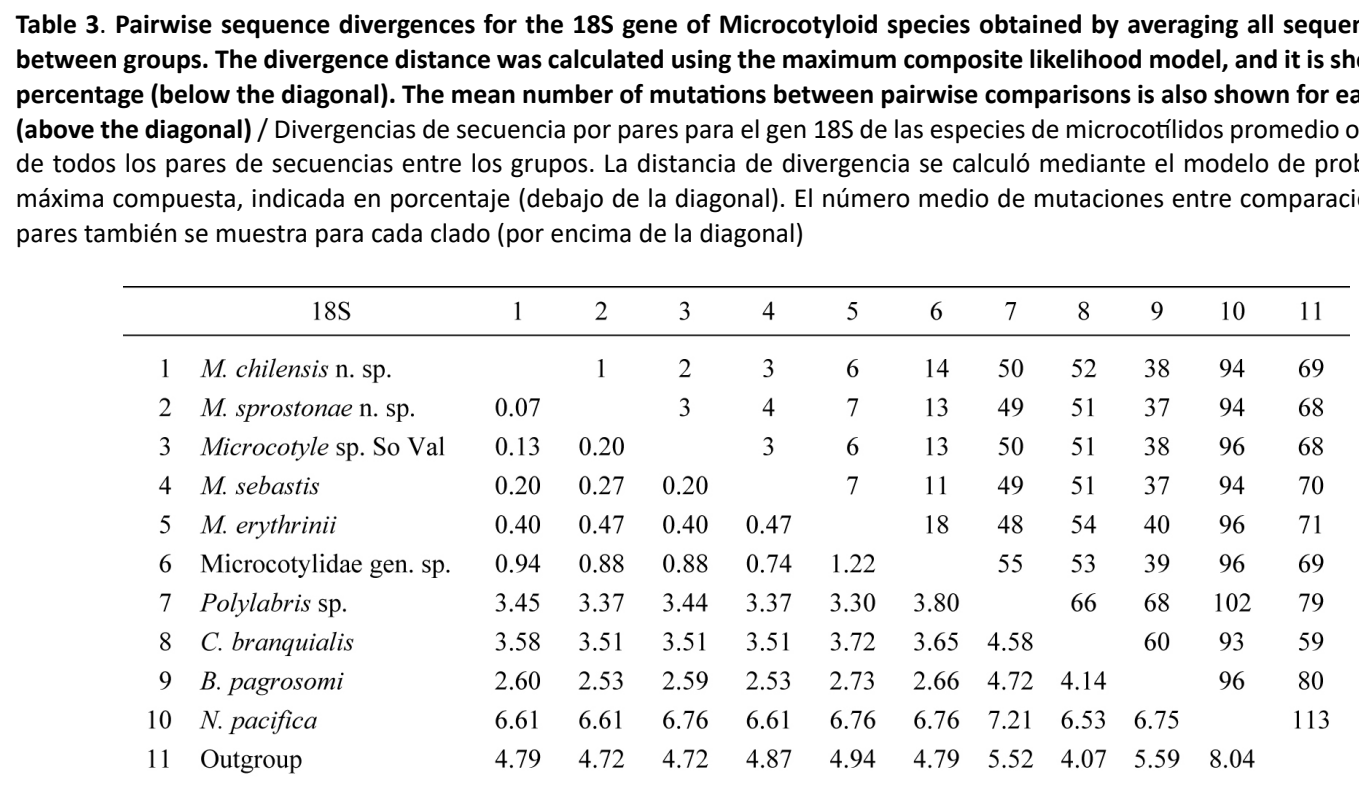


Based upon the ITS2 gene, there were also two clades of Microcotyle: one clade composed of monogeneans attached to the fish $S$. viridis and $H$. sordidus from central and from northern Chile (Antofagasta, $23^{\circ} \mathrm{S}$ ) (Fig. 4). These specimens were described as M. sprostonae $\mathrm{n}$. sp. Another clade was only composed Microcotyle from fish from the south-central region of Chile. These specimens were described as $M$. chilensis n. sp.
Specimens of M. sprostonae n. sp. did not differ in the genetic sequences for the ITS2 or 18S rDNA genes (Tables 4 and 5) even when the monogeneans were collected in localities far away from one another (Valparaíso $33^{\circ} \mathrm{S}$ and Antofagasta $23^{\circ} \mathrm{S}$, Table 1). However, M. sprostonae n. sp. and M. chilensis n. sp. differed by one base pair in both genes (ITS2 and 18S), which was supported by the phylogenetic analyses (NJ, ML, and MP) (Tables 3 and 4). Hence, molecular analyses confirmed the presence of two Microcotyle species in intertidal fish on the coast of Chile.

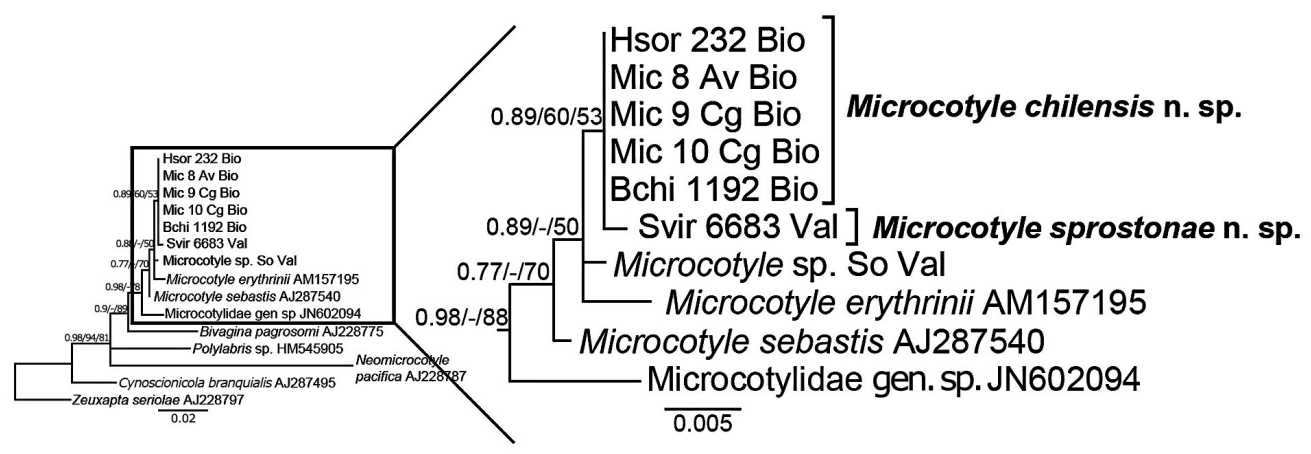

Figure 3. Phylogenetic tree showing the relationships among the microcotylids, including the two new species described in this study. The phylogenetic tree is based on $\mathrm{NJ}$ analyses of $18 \mathrm{~S}$ gene sequences. The numbers along the branches indicate the percentage of supporting values obtained from the different analyses in the following order: NJ, ML, and MP. Low values ( $<0.5$ for $\mathrm{NJ}$ and $<50 \%$ for ML and MP) are indicated with dashes. Abbreviations of regions of Chile: VAL: Valparaíso (central); BIO: Biobío (central-South). Fish names: Hsor: H. sordidus, Svir: S. viridis, Bchi: B. chilensis, Av: A. variolosus, Cg: C. geniguttatus, So: S. oculatus / Árbol filogenético que muestra las relaciones entre las especies de microcotilidos, incluidas las dos nuevas especies descritas en este estudio, basado en los análisis de NJ de las secuencias del gen 18S. Los números a lo largo de las ramas indican el porcentaje de valores de respaldo de los diferentes análisis en el siguiente orden: NJ, ML y MP. Los valores bajos se indican con guiones (<0,5 para NJ y $<50 \%$ para ML y MP). Abreviaciones de las regiones de Chile: VAL: Valparaíso (central); BIO: Biobío (centro-sur). Nombres de peces: Hsor: H. sordidus, Svir: S. viridis, Bchi: B. chilensis, Av: A. variolosus, Cg: C. geniguttatus, So: S. oculatus

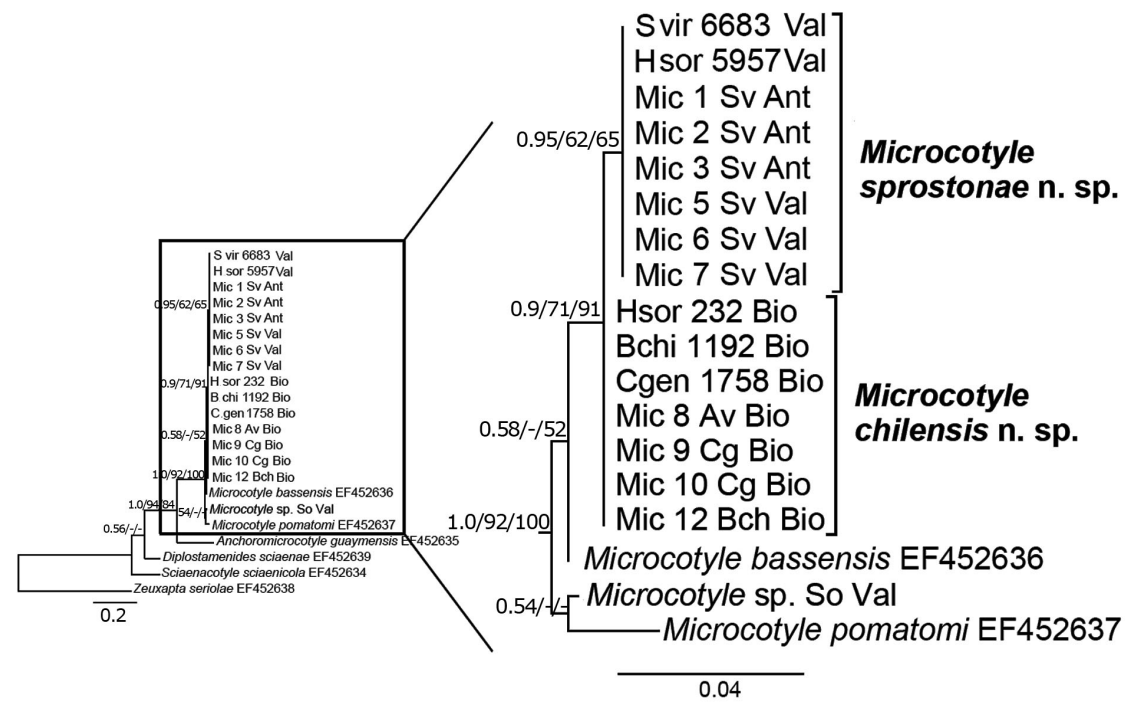

Figure 4.- Phylogenetic tree showing the relationships among the microcotylds, including the two new species described in this study. The phylogenetic tree is based on NJ analyses of ITS2 gene sequences. The numbers along the branches indicate the percentages of supporting values resulting from the different analyses in the following order: NJ, ML, and MP. Low values ( $<0.5$ for NJ, and $<50 \%$ for ML and MP) are indicated with dashes. Abbreviations as in Figure $\mathbf{3}$ / Árbol filogenético que muestra las relaciones entre las especies de microcotílidos, incluidas las dos nuevas especies descritas en este estudio, basado en los análisis de NJ de las secuencias del gen ITS2. Los números a lo largo de las ramas indican los porcentajes de los valores de respaldo resultantes de los diferentes análisis en el siguiente orden: NJ, ML y MP. Los valores bajos se indican con guiones (<0,5 para NJ y $<50 \%$ para ML y MP). Abreviaciones como en la Figura 3 
Table 4. Pairwise sequence divergence for the ITS2 gene of Microcotyloid species obtained by averaging all sequence pairs between groups. The divergence distance was calculated using the maximum composite likelihood model, and it is shown as a percentage (below the diagonal). The mean number of mutations between pairwise comparisons is also shown for each clade (above the diagonal) / Divergencia de secuencias por pares para el gen ITS2 de las especies de microcotiloides promedio obtenidas de todos los pares de secuencias entre los grupos. La distancia de divergencia se calculó mediante el modelo de probabilidad máxima compuesta, indicada en porcentaje (debajo de la diagonal). El número medio de mutaciones entre comparaciones por pares también se muestra para cada clado (por encima de la diagonal)

\begin{tabular}{llrrrrrrrrr}
\hline \multicolumn{1}{c}{ ITS2 } & 1 & 2 & 3 & 4 & 5 & 6 & 7 & 8 & 9 \\
\hline 1 & M. chilensis n. sp. & & 1 & 3 & 2 & 6 & 85 & 78 & 97 & 177 \\
2 & M. sprostonae n. sp. & 0.27 & & 4 & 3 & 7 & 86 & 79 & 98 & 178 \\
3 & Microcotyle sp. So Val & 0.81 & 1.09 & & 1 & 3 & 84 & 77 & 97 & 178 \\
4 & M. bassensis & 0.54 & 0.81 & 0.27 & & 4 & 84 & 77 & 97 & 178 \\
5 & M. pomatomi & 1.64 & 1.92 & 0.82 & 1.09 & & 86 & 79 & 100 & 179 \\
6 & D. sciaenae & 27.80 & 28.22 & 27.38 & 27.38 & 28.37 & & 92 & 61 & 174 \\
7 & A. guaymensis & 25.28 & 25.68 & 24.88 & 24.88 & 25.77 & 30.90 & & 100 & 182 \\
8 & S. sciaenicola & 32.77 & 33.23 & 32.67 & 32.67 & 34.17 & 18.80 & 34.54 & & 178 \\
9 & Outgroup & 82.54 & 83.54 & 83.15 & 83.15 & 84.81 & 81.99 & 89.77 & 85.47 & \\
\hline
\end{tabular}

Table 5. Differences in morphometric measurements of the two new species in this study, $M$. sprostonae $n$. sp. and $M$. chilensis n. sp. / Diferencias en las mediciones morfométricas de las dos nuevas especies, M. sprostonae n. sp. y M. chilensis n. sp.

\begin{tabular}{lcc}
\hline \multicolumn{1}{c}{ Variables } & $\begin{array}{c}\text { M. sprostonae } \\
\text { n. sp. }\end{array}$ & $\begin{array}{c}\text { M. chilensis } \\
\text { n. sp. }\end{array}$ \\
\hline Length & $3,062-5,225$ & $2,187-4,062$ \\
Width & $687-1,250$ & $475-1125$ \\
Length/Width & $3.3-5.8$ & $3.5-5.5$ \\
Total number of testes & $22-31$ & $14-18$ \\
Total number of clamps & $52-83$ & $44-54$ \\
Distance from anterior end to ovary (DAE-OV) & $1,200-2,050$ & $1,050-2,310$ \\
\% DAE-OV/ length & $33.9-46.3 \%$ & $42.4-61.8 \%$ \\
Distance from anterior edge to first vitellarium gland (DAE-FVG) & $112-750$ & $350-800$ \\
\% DAE-FVG/Length & $2.0-19.3 \%$ & $14.4-28.7 \%$ \\
Distance from posterior edge to last vitellarium gland (DPE-LVG) & $500-950$ & $300-550$ \\
\% DPE-LVG/Length & $13.1-24.5$ & $7.5-16.2$ \\
Ratio OSL/PhL & $1.01-1.75$ & $0.74-1.04$ \\
\hline
\end{tabular}

DAE: distance from anterior edge; DPE: distance from posterior edge; FVF: first vitelline follicle; LVG: last vitelline follicle; OV: ovary; OSL: oral sucker length; PhL: pharynx length

\section{Discussion}

In this study, two new species of Microcotyle were morphologically described, which was also supported by molecular data. Relative measurements, as suggested by Machkewskyi et al. (2013) were also useful for making comparisons among species, especially between $M$. sprostonae n. sp. and M. chilensis n. sp. The two species described here are parasites of sympatric fish, which are distributed along the Chilean coast. However, these Microcotyle species have different distributions. One is in south-central Chile (M. chilensis n. sp.), and the other is in northern and central Chile (M. sprostonae n. sp.).

Distinctions in morphology between these two species cannot be attributed to the geographic distance for the following four reasons. (1) Molecular data were based on a variable gene (ITS2) and a conserved gene (18S). Both genes differed between species, and that difference was consistent in all host species and geographical zones. (2) Almost 200 specimens of $S$. viridis were collected in southcentral Chile (Table 1), but none of them were parasitized by $M$. sprostonae n. sp., despite $C$. geniguttatus being collected in the same habitat at the same time with a high level of parasitization by M. chilensis $\mathrm{n}$. sp. In contrast, in central Chile, most $S$. viridis collected were parasitized by microcotylids (M. sprostonae n. sp.). In 109 specimens of C. geniguttatus, only two were parasitized by microcotylids (one parasite per fish). One of these monogeneans was fixed in ethanol, but, unfortunately, DNA amplification was not successful. However, its morphology is consistent with that of M. sprostonae n. sp. In addition, three specimens of $S$. viridis were collected in northern Chile. All of them

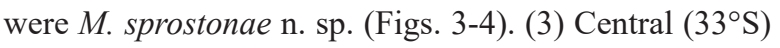
and south-central $\left(36^{\circ}\right)$ zones of Chile are $600 \mathrm{~km}$ away. In both locations, different Microcotyle species were found. 
While the central $\left(33^{\circ} \mathrm{S}\right)$ and northern $\left(23^{\circ} \mathrm{S}\right)$ zones of Chile are $1300 \mathrm{~km}$ apart, M. sprostonae n. sp. was in both localities. Therefore, the geographic distance alone does not explain the presence of different Microcotyle species. It is probable that environmental conditions, which change across latitudes, may affect the distribution and host specificity of Microcotyle. (4) The presence of Microcotyle species in one zone versus another was not due to fish body sizes, because $S$. viridis and $C$. geniguttatus were similar in body length between sampling zones (Table 1). Altogether, there is sufficient morphological, molecular, and ecological evidence to confirm the validity of the two Microcotyle species described here.

Microcotyle sprostonae $\mathrm{n}$. sp. and M. chilensis $\mathrm{n}$. sp. were present on hosts of different families, although each species showed a preference for a certain host species (based on the high abundance and prevalence of the parasite). Also, a host species, Hypsoblennius sordidus, can be parasitized by both monogeneans separately, depending on the geographical distribution of the parasite. This result indicates that it is not possible to assume fish of the same species from different localities have the same Microcotyle species or that Microcotyle from different host species are different (Martínez \& Barrantes 1977).

The genus Microcotyle requires the reassessment of many species, which is a very difficult task to carry out because several of the species considered valid need revision. Moreover, over time, more morphological details have been incorporated, and thus descriptions have become more complex. Consequently, the characteristics and distinctions of the recent new species are well understood, but the simplicity of the original descriptions for many of the species described long ago generates more doubts about the validity of those species. Also, it is worth noting that some characteristics may change with age, such as body width, number of clamps, and egg size (Sproston 1946). Thus, future studies need to considerate several specimens in order to establish the variability of any morphological trait. The descriptions of a species should consider as many morphological features as possible, which should be documented in measurements and figures. Molecular techniques are good tools for species descriptions; however, the molecular approach has been applied only recently, considering so far just a few species of Microcotyle, and therefore the advantages of genetic analyses for identification purposes are still limited for this genus. Therefore, future studies may include molecular methods to complement the species descriptions (new and already known), in order to clarify the status of numerous species in Microcotyle and in any other genera within Microcotylidae.

\section{ACKNOWLEDGMENTS}

This study was supported by the FONDECYT Regular Grant 1130304 (to MG-N). We thank Natalia Leiva for providing specimens of Microcotyle from Antofagasta, and Zambra López for her help with the molecular analyses. We thank several assistants, who helped us in different stages of this study, including Marlene Pizarro, Pauline Villegas, and Juan Soto. We also appreciate many people (the list is too long to include here), who helped us obtain the literature used in this study. However, we want to specifically mention Dr. Lin Liu, who kindly translated one Chinese paper, and Ms. Elena Selezneva, who translated some Russian papers. We thank Jeanette Santana (librarian) and David Jara (computer manager), who are staff at the Universidad de Valparaiso, and assisted us in different ways during this research project. We also thank the suggestions of two anonymous reviewers, who help a lot to improve this manuscript. Finally, we thank those journals and web pages that provided scientific information without charges. Thus, we want to say that "scientific articles must be free and for everyone".

\section{LITERATURE CITED}

Aljanabi SM \& I Martinez. 1997. Universal and rapid saltextraction of high quality genomic DNA for PCR-based techniques. Nucleic Acids Research 25: 4692-4693.

Anderson GR \& SC Barker. 1993. Species differentiation in the Didymozoidae (Digenea): restriction fragment length differences in internal transcribed spacer and $5.8 \mathrm{~S}$ ribosomal DNA. International Journal for Parasitology 23: 133-136.

Ayadi ZE, D Gey, J-L Justine \& F Tazerouti. 2017. A new species of Microcotyle (Monogenea: Microcotylidae) from Scorpaena notata (Teleostei: Scorpaenidae) in the Mediterranean Sea. Parasitology International 66: 37-42.

Badets M, I Whittington, F Lalubin, JF Allienne, JL Maspimby, S Bentz, LH Du Preez, D Barton, H Hasegawa, V Tandon, R Imkongwapang, A Ohler, C Combes \& O Verneau. 2011. Correlating early evolution of parasitic platyhelminths to Gondwana breakup. Systematic Biology 60(6): 762-781.

Balboa L \& M George-Nascimento. 1998. Variaciones ontogenéticas y entre años en las infracomunidades de parásitos metazoos de dos especies de peces marinos de Chile. Revista Chilena de Historia Natural 71: 27-37.

Bouguerche C, D Gey, JL Justine \& F Tazerouti. 2019a. Microcotyle visa $\mathrm{n}$. sp. (Monogenea: Microcotylidae), a gill parasite of Pagrus caeruleostictus (Valenciennes) (Teleostei: Sparidae) off the Algerian coast, Western Mediterranean. Systematic Parasitology 96(2): 131-147.

Bouguerche C, D Gey, JL Justine \& F Tazerouti. 2019b. Towards the resolution of the Microcotyle erythrini species complex: description of Microcotyle isyebi $\mathrm{n}$. $\mathrm{sp}$. (Monogenea, Microcotylidae) from Boops boops (Teleostei, Sparidae) off the Algerian coast. Parasitology Research 118: 1417-1428. 
Bowles J, M Hope, WU Tiu, XS Liu \& DP McManus. 1993. Nuclear and mitochondrial genetic markers highly conserved between Chinese and Philippine Schistosoma japonicum. Acta Tropica 55: 217-229.

Bray RA. 2001. Monogenea. In: Costello MJ, C Emblow \& R White (eds). European register of marine species: a checklist of the marine species in Europe and a bibliography of guides to their identification. Collection Patrimoines Naturels 50: 142-146

Bush AO, KD Lafferty, JM Lotz \& AW Shostak. 1997. Parasitology meets ecology on its own terms: Margolis et al. revisited. The Journal of Parasitology 83: 575-583.

Caballero E \& M Bravo-Hollis. 1972. Monogenea (van Beneden, 1858) Carus, 1863 de peces marinos del litoral mexicano del Golfo de México y del Mar Caribe. V. Revista de Biología Tropical 20: 151-165.

Díaz F \& M George-Nascimento. 2002. Estabilidad temporal de las infracomunidades de parásitos en la borrachilla Scartichthys viridis (Valenciennes, 1836) (Pisces: Blenniidae) en la costa central de Chile. Revista Chilena de Historia Natural 75: 641-649.

Díaz P \& G Muñoz. 2010. Diet and parasites of the insular fish Scartichthys variolatus (Blenniidae) from Robinson Crusoe Island, Chile: How different is this from two continental congeneric species? Revista de Biología Marina y Oceanografía 45: 293-301.

Dillon WA \& WJ Hargis. 1965. Monogenetic trematodes from the southern Pacific Ocean. 2. Polyophisthocotyleids from New Zealand fishes: the families Discocotylidae, Microcotylidae, Axinidae and Gastrocotylidae. Biology of Antarctic Seas II. Antarctic Research Series 5: 251-280.

Flores K \& M George-Nascimento. 2009. Las infracomunidades de parásitos de dos especies de Scartichthys (Pisces: Blenniidae) en localidades cercanas del norte de Chile. Revista Chilena de Historia Natural 82: 63-71.

Gonzalez MT \& CA Moreno. 2005. The distribution of the ectoparasite fauna of Sebastes capensis from the southern hemisphere does not correspond with zoogeographical provinces of free-living marine animals. Journal of Biogeography 32: 1539-1547.

Goto S. 1899. Notes on some exotic species of ectoparasitic trematodes. Journal of the College of Science, Imperial University of Tokyo 12: 263-295.

Hayward CJ, NJ Bott, N Itoh, M Iwashita, M Okihiro \& BF Nowak. 2007. Three species of parasites emerging on the gills of mulloway, Argyrosomus japonicus (Temminck and Schlegel, 1843), cultured in Australia. Aquaculture 265: 27-40.

Kimura M. 1980. A simple method for estimating evolutionary rate of base substitutions through comparative studies of nucleotide sequences. Journal of Molecular Evolution 16: 111-120.

Littlewood DTJ \& PD Olson. 2001. SSU rDNA and the Platyhelminthes: signal, noise, conflict and compromise. In: Littlewood DTJ \& RA Bray (eds). Interrelationships of the Platyhelminthes, pp. 262-278. Taylor \& Francis, London.
Machkewskyi VK, EV Dmitrieva, S Al-Jufaili \& NAM AlMazrooei. 2013. Microcotyle omanae $\mathrm{n}$. sp. (Monogenea: Microcotylidae) a parasites from Cheimerius nufar (Valenciennes) (Sparidae) from the Arabian Sea. Systematic Parasitology 86: 153-163.

Mamaev YL. 1977. One classifications of the monogeneans of the Microcotylidae family. Parazitologiya 11: 98-103. [In Russian]

Mamaev YL. 1986. The taxonomical composition of the family Microcotylidae Taschenberg, 1879 (Monogenea). Folia Parasitologica 33: 199-206.

Mamaev YL. 1989. On species composition and morphological features of the genus Microcotyle (Microcotylidae, Monogenoidea). In: Lebedev BI (ed). Investigations in parasitology, collection of papers, pp. 32-38. DVNTs SSSR, Vladivostok. [In Russian]

Martínez R \& I Barrantes. 1977. Helmintos parásitos de Cheilodactylus variegatus Valenciennes, 1833, "pintadilla". I. Paramicrocotyle danielcarrioni n. sp. (Monogenea: Microcotylidae). Biota 11(88): 139-146.

Muñoz G \& R Castro. 2012. Comunidades de parásitos eumetazoos de peces labrisómidos de Chile central. Revista de Biología Marina y Oceanografía 47: 565-571.

Muñoz G \& N Delorme. 2011. Variaciones temporales de las comunidades de parásitos de peces intermareales de Chile central: hospedadores residentes vs temporales. Revista de Biología Marina y Oceanografía 43: 313-327.

Muñoz G \& V Olmos. 2007. Revisión bibliográfica de especies ectoparásitas y hospedadoras de sistemas acuáticos de Chile. Revista de Biología Marina y Oceanografía 42: 89-148.

Muñoz G \& H Randhawa. 2011. Monthly variation in the parasite communities of the intertidal fish Scartichthys viridis (Blenniidae) from central Chile: are there seasonal patterns? Parasitology Research 109: 53-62.

Muñoz G, V Valdebenito \& M George-Nascimento. 2002. La dieta y la fauna de parásitos metazoos del torito Bovichthys chilensis Regan 1914 (Pisces: Bovichthydae) en la costa de Chile centro-sur: variaciones geográficas y ontogenéticas. Revista Chilena de Historia Natural 75: 661-671.

Muñoz-Muga P \& G Muñoz. 2010. Comunidades de parásitos de Scartichthys viridis (Pisces: Blenniidae) de Chile central: localidad vs. longitud del hospedador. Revista de Biología Marina y Oceanografía 45: 165-169.

Peña MF, E Poulin, GPM Dantas, D González-Acuña, MV Petry \& JA Vianna. 2014. Have historical climate changes affected gentoo penguin (Pygoscelis papua) populations in Antarctica? PLoS ONE 9: e95375. <DOI: 10.1371/journal. pone.0095375>

Sandars DF. 1944. A contribution to the knowledge of the Microcotylidae of Western Australia. Transactions of the Royal Society of South Australia 68: 67-81.

Sproston NG. 1946. A synopsis of the monogenetic trematodes. Transactions of Zoological Society of London 25: 185-600.

Tamura K, G Stecher, D Peterson, A Filipski \& S Kumar. 2013. MEGA6: Molecular Evolutionary Genetics Analysis version 6.0. Molecular Biology and Evolution 30: 27252729 . 
Tateno Y, N Takezaki \& M Nei. 1994. Relative efficiencies of the maximum-likelihood, neighbor-joining, and maximumparsimony methods when substitution rate varies with site. Molecular Biology and Evolution 11(2): 261-277.

Thoney DA \& TA Munroe. 1987. Microcotyle hiatulae Goto, 1900 (Monogenea), a senior synonym of $M$. furcata Linton, 1940 , with a redescription and comments on postlarval development. Proceedings of Helminthology 54: 91-95.

Unnithan RV. 1971. On the functional morphology of new fauna of Monogenoidea of fishes from Trivandrum and environs. Part IV. Microcotylidae sensu stricto and its repartition into subsidiary taxa. American Midland Naturalist 85: 366-398.

Van Beneden PJ \& CE Hesse. 1863. Second appendice au Mémoire - Sur les Bdellodes et les trématodes. Mémories de 1'Académie Royale de Belgique 34: 62-149.

Verma AK, J Verma \& N Agrawal. 2018. Redescription and new host record of Diplostamenides sciaenae (Monogenea, Microcotylidae) and its phylogenetic status using molecular markers Vestnik Zoologii 52(1): 37-46.
Villalba C \& J Fernández. 1986. Dos nuevas especies de tremátodos parásitos de peces marinos en Chile. Parasitología al Día 10: 45-51.

Yamaguti S. 1940. Studies on the helminth fauna of Japan Part 31. Trematodes of fishes, VII. Japanese Journal of Zoology 9: 35-108.

Yamaguti S. 1963. Systema Helminthum. IV. Monogenea and Aspidogastrea, 699 pp. Interscience Publishers, New York.

Yamaguti S. 1968. Monogenetic trematodes of Hawaiian fishes, 287 pp. University of Hawaii Press, Honolulu.

Yoon GH, S Al-Jufaili, MA Freeman, JE Bron, G Paladini \& AP Shinn. 2013. Omanicotyle heterospina n. gen. et n. comb. (Monogenea: Microcotylidae) from the gills of Argyrops spinifer (Forsskal) (Teleostei: Sparidae) from the Sea of Oman. Parasites \& Vectors 6(1):170. $<$ doi:10.1186/1756-3305-6-170>

Received 22 May 2019 and accepted 14 October 2019

Editor: Claudia Bustos D. 